International Journal of Physical Sciences and Engineering
Available online at http://sciencescholar.us/journal/index.php/ijpse
Vol. 2 No. 1, April 2018, pages: 57 70
e-ISSN : 2550-6943, p-ISSN : 2550-6951
http://dx.doi.org/10.29332/ijpse.v2n1.130

\title{
A Feasibility Study for Social and General Facilities in Perumnas Tanjung Karang Permai Mataram
}

\author{
Baiq Susdiana Fibrianti a, Heri Sulistiyono ${ }^{b}$, Hartana $^{c}$
}

Article history: Received 5 October 2017, Accepted in revised form 20 February 2018, Approved 1 March 2018, Available online 3 April 2018

\section{Correspondence Author}

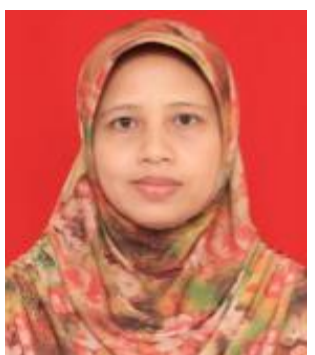

\section{Keywords}

Feasibility study; General facilities; Mataram;

Population growth; Public facilities;

\begin{abstract}
The increasing number of population growth affects the emergence of problems in Perumnas Tanjung Karang Permai to be more complex, one of them is situation problem, availability of social facilities and public facilities. Thus, it is necessary to sight more in-depth of the feasibility of availability, condition, and management of social and public facilities in PERUMNAS Tanjung Karang Permai Mataram. Standardized feasibility is taken from the Regional Regulation of Mataram City No. 4 the year 2016 Article 9 saying about the provision of infrastructure by the developer at least $30 \%$ of the land area of housing and standard that is currently set by the government namely SNI 03-1733-2004 on the procedures of regional planning housing town. This study aims at identifying the level of availability, condition or capacity of social facilities and public facilities to the needs of the population seen from the population and land area of social facilities and public facilities. The existence of location mapping of Social Facilities and Public Facilities is to explain the availability and spatial aspects of the condition in Perumnas Tanjung Karang Permai Mataram. The analysis is done by comparing the number of population with the availability of social facilities and public facilities. If there is an imbalance between the availability of social facilities and public facilities with the total population, then the existing condition can be said to be inadequate. Therefore, for the evaluation of the existing condition becomes an input for service improvement in the future. Conversely, if the results of the performance evaluation analysis state that there is a balance or an excess, then the performance of housing services is said to be adequate or adequate. From the study that will be exposed whether or not the availability of social facilities and public facilities in Perumnas Tanjung Karang Permai suitable with current rules and standards, or additional facilities are required. What the condition of the facilities and infrastructure at this time is and how also its management so far is. The feasibility of a means of infrastructure is not only seen from the existence or the availability but it also needs to be seen from the aspects of maintenance, care, and management in the future in order to make it always function properly.
\end{abstract}

a Mataram University, Indonesia

b Mataram University, Indonesia

c Mataram University, Indonesia 
e-ISSN: 2550-6943, p-ISSN: 2550-6951 ${ }^{\circ}$ Copyright 2018. The Author.

SS Journals Published by Universidad Técnica de Manabí.

This is an open-access article under the CC BY-SA 4.0 license

(https://creativecommons.org/licenses/by-sa/4.0/)

All rights reserved.

\section{Contents}

Abstract

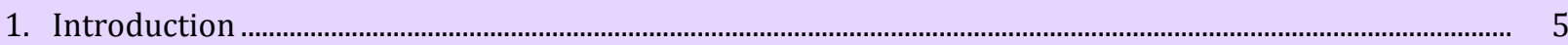

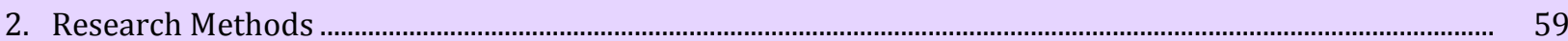

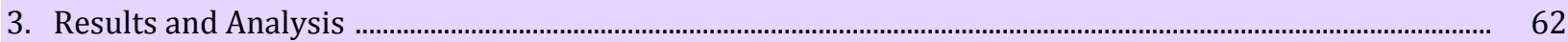

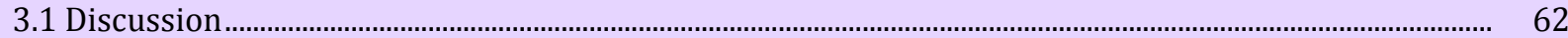

3.2 Recapitulation of Analysis of Social Facilities in Perumnas Tanjung Karang Permai Mataram............. 63

4. Conclusion

Conflict of interest statement and funding sources............................................................................................... 67

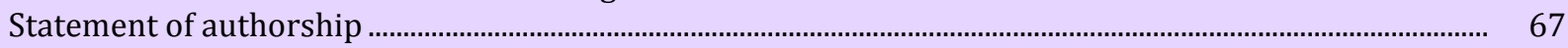

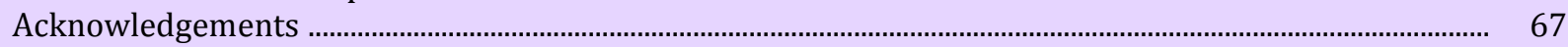

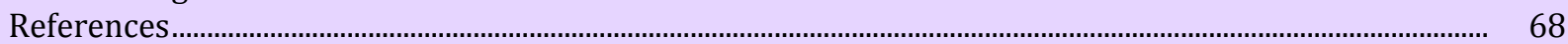

Biography of Authors ............................................................................................................................................. 70

\section{Introduction}

The urban area is defined as a residential area with a population density greater than the density of national territory. Besides, urban areas have non-agrarian livelihood structures, have a diversity of socioeconomic activities, diverse land uses and the presence of adjacent physical buildings. The largest use of land in urban areas is for housing. The provision of social facilities and public facilities constituting the public spaces of an urban area and environment cannot be separated from the overall space management for the provision of infrastructure in residential areas. The problem of social facilities and public facilities in the housing environment is the lack of facilities so that many citizens are disappointed. Moreover, many citizens build social facilities - public facilities by themselves when in fact they should be provided by the government. To meet the need for housing nationally, in 1974 the Indonesian government constructed Perumnas (National housing). One of them is the construction of Perumnas Tanjung Karang Permai. Perumnas Tanjung Karang Permai Mataram was built in 1981 and is one of the oldest national housings in Mataram with a land area of $261,401 \mathrm{sqm}$ and ranges from $70 \mathrm{~m}^{2}$ to $100 \mathrm{~m}^{2}$. In the early stage of construction, the condition of the environmental road in this area is approximately 4 meters wide and have limited access to transportation modes.

Along with the increase of population growth, the problems in Perumnas Perumnas Tanjung Karang Permai become increasingly complex one of them is the condition and availability of social facilities and public facilities. Regional Regulation of Mataram City No. 4 the Year 2016 Article 9 saying that every developer of housing is not compiled, he or she shall provide infrastructure, facilities, and utilities with the proportion of at least $30 \%$ of the developed land area. Based upon this description and problems, it needs more concern on the feasibility of availability, condition, and management of social facilities and public facilities at PERUMNAS Tanjung Karang Permai Mataram City and refers to SNI 03-1733-2004 standards.

There are several problems formulated in this study include; (1) the availability of social facilities and public facilities in PERUMNAS Tanjung Karang Permai still needs to be reviewed whether or not it is in compliance with the existing regulations with minimum requirements that must be provided by the developer that is $30 \%$ of the total land area of settlement, (2) the increasing number of settlement residents has resulted in the increasing need for social facilities and public facilities. In this case, it is necessary to review whether or not the condition of infrastructure facilities that are part of social facilities and public facilities in PERUMNAS Tanjung Karang Permai is still able to meet the needs of its inhabitants, and (3) as the oldest PERUMNAS in Mataram City even in West Nusa Tenggara, it needs to be reviewed how the sustainability of the management 
of social facilities and public facilities in the housing so that existing facilities can be utilized by the community.

\section{Research Methods}

This study is categorized study as a qualitative descriptive by including quantitative data as supporting analysis. The method of this research is using the normative method. This research was conducted at Perumnas Tanjung Karang Permai, Sekarbela, Mataram City. Data collection was done by conducting primary and secondary data surveys. This research uses technical analysis method including (1) Minimum Service Standard (SPM) analysis aims at identifying the level of service of social facilities and public facilities to the needs of the population. Analysis of service standards is done by comparing the minimum service standard (SPM) with service availability. SPM as a reference, in this case, is the SNI 03-1733-2004 on the Procedures of environmental planning in urban housing. If there is an imbalance between the existing housing conditions and the standard of population needs, then the existing condition can be said to be feasible and (2) the analysis aims at identifying the level of availability, condition or carrying capacity of social facilities and public facilities to the needs of the population based on the population and land area of social facilities and public facilities at Perumnas Tanjung Karang Permai Mataram. The data analysis was done by comparing the number of population with the availability of social facilities and public facilities. If there is an imbalance between the availability of social facilities and public facilities with the total population, then the existing condition can be said to be infeasible. Therefore, for the evaluation of the existing condition becomes an input for service improvement in the future. Conversely, if the results of the performance evaluation analysis state that there is a balance or an excess, then the performance of housing services is said to be feasible.

The technical standards of the research analysis of social facilities refer to the needs of the people in the settlement environment, namely: government facilities and public services, educational and learning facilities, health facilities, means of worship, shopping and commercial facilities, sports facilities and open fields, public cemeteries. And the technical standard used as a benchmark for the feasibility of social facilities, namely Indonesian National Standard (SNI) 03-1733-2004, is a standard set by the National Standardization Agency and is applied nationally on the Procedures of Urban Housing Planning. Standard of Land Provision for Housing Facilities.

Tabel 1

Number of Residents of Perumnas Tanjung Karang Permai per- Environment

\begin{tabular}{|c|c|c|}
\hline No. & Name of Area or Environment & Population Number (Person) \\
\hline 1. & Batanghari & 721 \\
\hline 2. & Barito & 1334 \\
\hline 3. & Kesejahteraan & 1903 \\
\hline \multirow[t]{2}{*}{4} & Asahan & 1548 \\
\hline & Total & 5506 \\
\hline
\end{tabular}

Source: Kelurahan Tanjung Karang Permai, 2016

Fibrianti, B., Sulistiyono, H., \& Hartana, -. (2018). A feasibility study for social and general facilities in Perumnas Tanjung Karang Permai Mataram. International Journal Of Physical Sciences And Engineering (IJPSE), 
Table 2

Data Base of Social Facilities and General Facilities

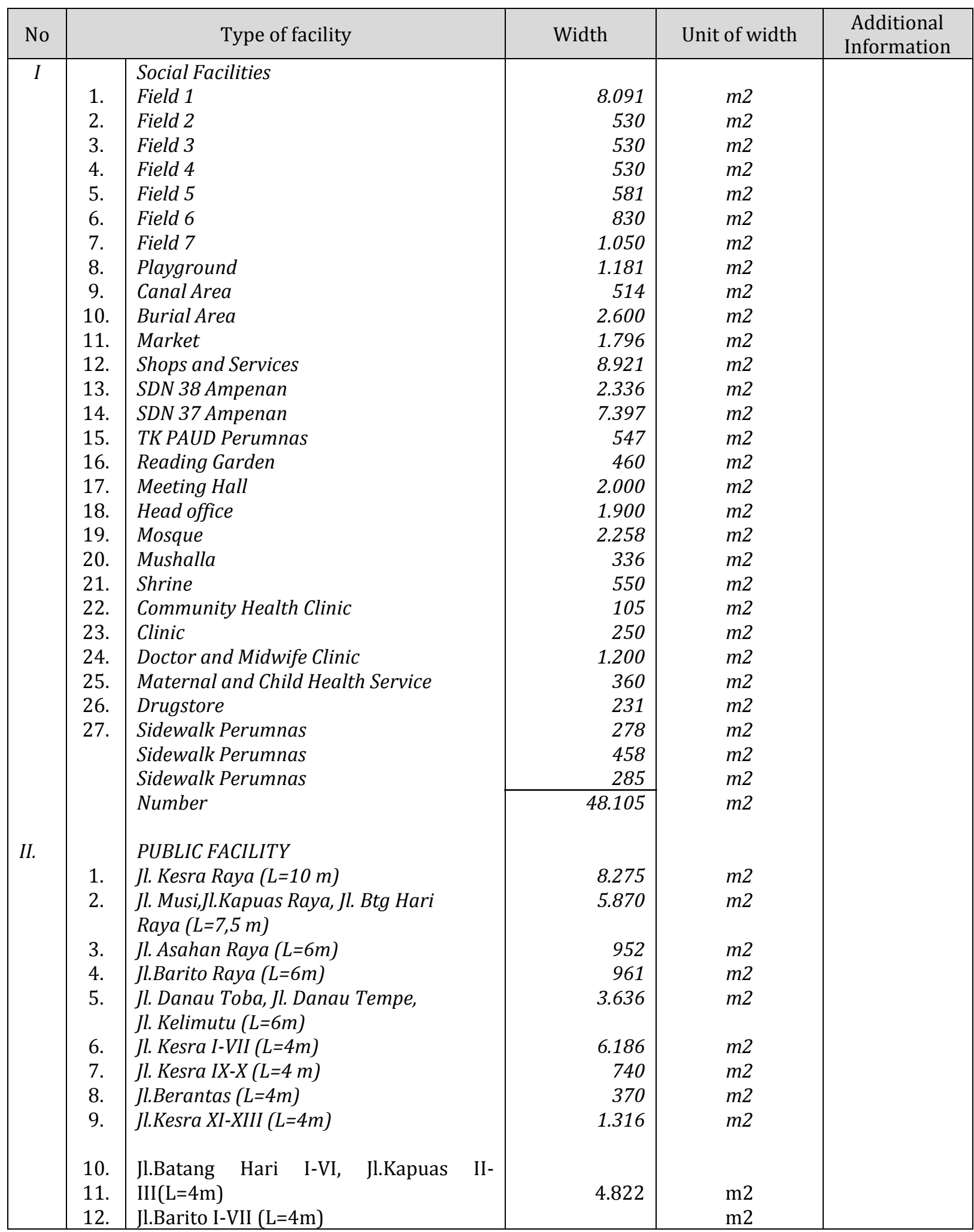




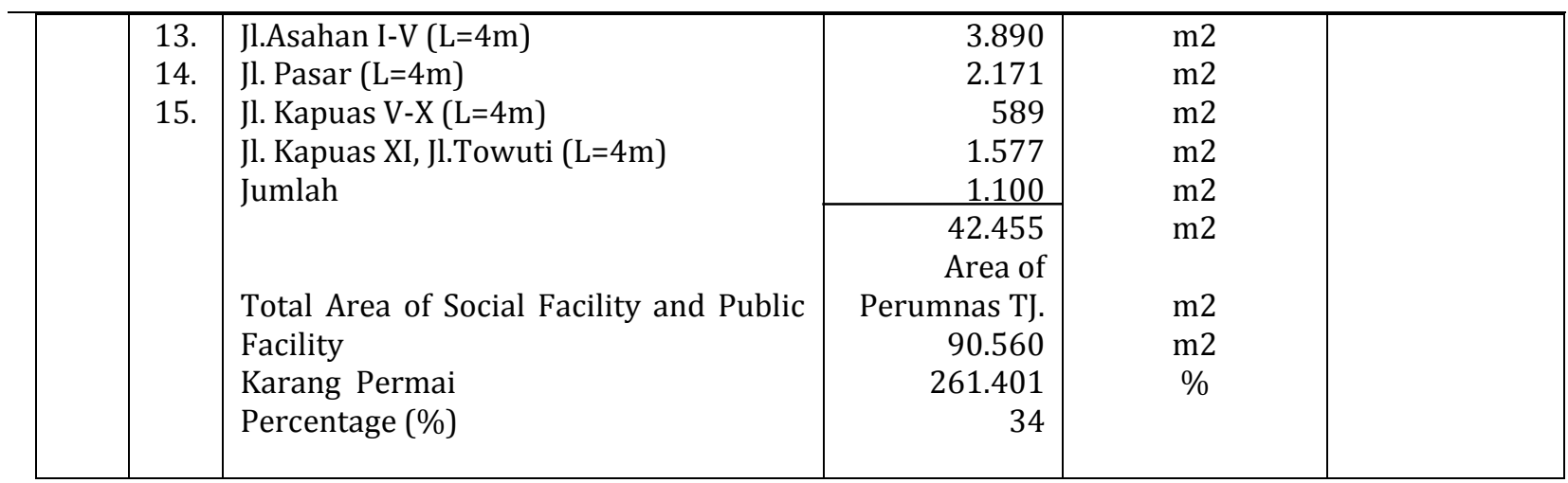

Theoretical Framework

According to Law No. 4 in 1992 on Housing and Settlements article 1, paragraph 2 and 3, housing is located and is part of the settlement. "Housing is a group of houses functioning as a residential environment equipped with environmental facilities and infrastructure" (article 1, paragraph 2) including basic physical environment such as drinking water supply, garbage disposal, electricity, telephone and roads, which enables the settlement environment to function properly; and environmental facilities that is supporting facilities functioning to organize and develop economic, social, and cultural life, such as playground facilities, sports, education, shops, transportation facilities, security, and other social facilities

"Settlements are part of the environment outside of protected areas, both in urban and rural areas functioning as living areas or residential environments and places of activity that support the life and livelihoods" (article 1 of 3).

Housing is one means of shelter closely related to the rules of community life. The residential area is a residential environment that needs to be protected from disturbances such as noise, dirt, smell, and others. Thus, in the housing area, there should be provided facilities and environmental infrastructures that support the activities of the community. Settlements are groups of houses equipped with physical and non-physical activities (Ministry of Public Works, 1987).

Tjuk Kuswartojo, et al; (2005), in his book Housing and Settlements in Indonesia state that formal housing is built with a clear or definite rule so that orderly pattern is constructed. When entering this area, it can be found the service and completeness of settlements designed before being inhabited or before becoming a settlement. Formal housing is built simultaneously with a development organization. It can also be built in succession or in some stages individually. But everything related to the building is ordered and controlled by a rule.

The main aim of the settlement unit is to develop and improve the environment or group of settlement environments.

Settlement on the outline consists of various components, namely:

a) Land designated for the settlement in which the condition of the land will affect the price of the units of houses built on the land.

b) Settlement infrastructure, i.e. local roads, drainage canal, sewerage, drainage, garbage, and electricity and telephone networks, all of which are components of infrastructure assisting to determine the quality of settlements built.

c) Housing (residence) which is built.

d) Public facilities and social facilities, namely educational facilities, health, worship, playground, and others in the neighborhood.

Fibrianti, B., Sulistiyono, H., \& Hartana, -. (2018). A feasibility study for social and general facilities in Perumnas Tanjung Karang Permai Mataram. International Journal Of Physical Sciences And Engineering (IJPSE), 


\section{Results and Analysis}

\subsection{Discussion}

Social Facilities and Public Facilities with total land area of 34\% is in line with the Regulation of Mataram City No 4 in 2016 article 9 on the provision of social facilities and public facilities at least $30 \%$ of the area of land provided, and this percentage is increased because of the facilities established by individuals/persons such as trade and service facilities including shops, stalls and service facilities, health facilities such as clinics, private health service by Doctor, private health service by midwife and drugstore. The explanation of various public service facilities in perfumes Tanjung Karang, as well as its location, can be seen in this scheme, as follows.

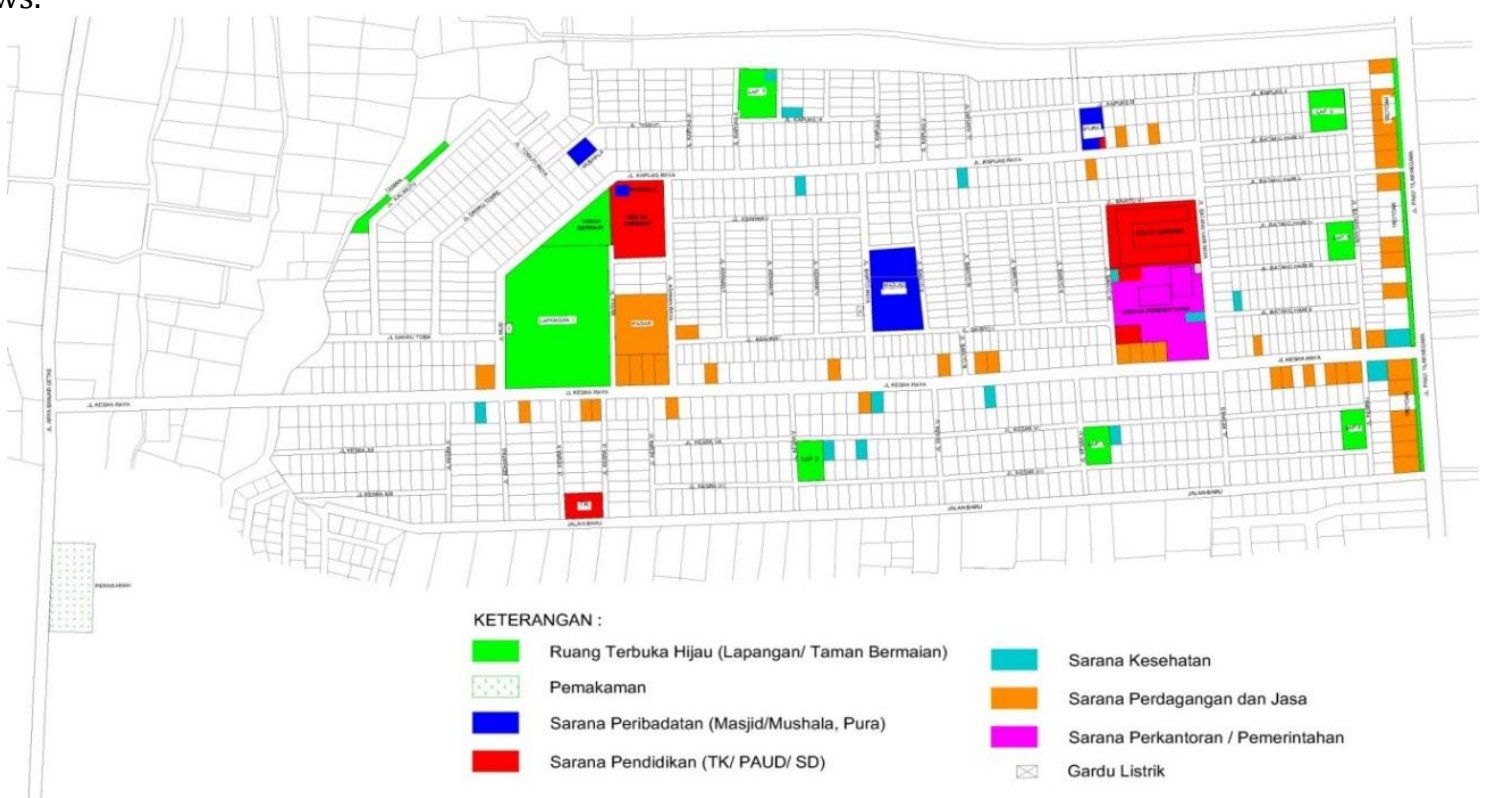

Figure 1. Map of Distribution of Social Facility at Perumnas Tanjung Karang Permai

Analysis of service standards intended in this study are:

a) In determining the standard size for urban residential environmental planning which includes the planning of residential facilities, infrastructure, and environmental facilities, using the approach of the density of the population and the extent of land social facilities and public facilities.

b) Analysis of service standards intended in this study is an assessment of the condition of services conducted by comparing the existing condition of social facilities and existing public facilities with the terms and conditions set by SNI 03-1733-2004.

c) Besides the existing provisions regulated by SNI 03-1733-2004, a comprehensive study of the availability of social facilities and public facilities is also seen from the other provisions of Mataram City Regulation No.4 year 2016 article 9 stating that each house non-storey house developer shall provide infrastructure, facilities and utilities with the proportion of at least $30 \%$ of the area land.

Education and Learning Facilities are located at several points which can be used simultaneously by the community of Perumnas Tanjung Karang Permai. There are educational facilities such as Kindergarten and Elementary School and study group. The area for this educational facility reaches $547 \mathrm{~m} 2$ for Kindergarten, 3,265 m2 for SDN 37 Ampenan, SDN 38 Ampenan for 2,336 m2 and $500 \mathrm{~m} 2$ for the reading garden. This education and learning facilities function is to provide early education facilities and basic education for the community, especially those living in Perumnas Tanjung Karang Permai.

This health facility is located at several points that can be accessed by a community of Tanjung Karang Permai. Some types of existing health facilities include Community Health Clinic, Maternal and Child Health Service, private doctor clinic, midwife clinic, pharmacies and private health clinics such as Clinic Assyifa 
function to provide health facilities for the community, especially those living in Perumnas Tanjung Coral Permai as first aid to the local community.

The availability of health facilities for every 1250 people based on SNI 03-1733-2004 requires Maternal and Child Health Service. Based on a survey at Perumnas Tanjung Karang Permai Mataram, the availability of health facilities with a population of 5506 people has been met health facilities. With a population of 5506 people in Perumnas Tanjung Karang Permai also has Community Health Clinic along with the existence of other health facilities such as midwife private clinic, Doctor private clinic, as well as the drugstore will certainly add the availability of health facilities. With the growth of health facilities developed by private enables public health services outside the environment of Tanjung Perumnas Karang Permai can be met.

The facilities of worship are available at several points that can be used together by the Community of Perumnas Tanjung Karang Permai. The existence of some types of worship facilities includes mosques, mashallah and shrine, is to provide facilities for the local community to do their worship activities, especially those living in Perumnas Tanjung coral Permai Mataram. Based on SNI 03-1733-2004 for every 250 persons, 1 (one) mushalla is established and for every 2500 people, 1 (one) mosque is established. Based on field observation for 5506 residents, Perumnas Tanjung Karang Permai has 2 (two) mushalla built by selfsupporting citizens and the other comes from the government and the needs of the mosque area of worship are 2,258 m2. Thus, the requirement of the facility of worship has fulfilled the standard of SNI 03-1733-2004. The condition of the facilities is comfortable and representative because there is the participation of local residents in maintaining. Physically, the building of existing worship facilities is still structurally and well maintained.

Trade and commercial facilities are spread in Perumnas Tanjung Karang Permai Mataram. Some types of trade and commerce facilities are market, private shop, stalls either located on the edge of the road kesra raya or in the houses spreading out. Its function is to provide trade and commercial activities for the Community at Perumnas Tanjung Karang Permai and the surrounding environment. The availability of Trade and Commerce facilities for every 250 persons based on SNI 03-1733-2004 requires shops/stalls and for every 6000 people based on SNI 03-1733-2004 requires shops. While in Perumnas Tanjung Karang Permai the population of 5506 inhabitants there is an environmental market with $1.900 \mathrm{~m} 2$ of land area and if it is seen based on SNI 03-1733-2004, every 30.000 inhabitants need a market. By looking at the number of residents Perumnas Tanjung Karang Permai that is 5506 inhabitants with a market, it can be said that trading facilities in the neighborhood are met. The existing market in Perumnas Tanjung Karang Permai is also utilized by Community outside of Perumnas Tanjung Karang Permai Mataram. There are also shops and services of 8,921 $\mathrm{m} 2$.

Open space facilities, parks, and sports field are located at several points and be used together by the Community of Perumnas Tanjung Karang Permai. Some kinds of open spaces, parks, and sports fields are the main square located beside Perumnas Tanjung Karang Permai market, but there are also playgrounds and green parks and smaller scale fields, its position is spreading around the housing block. Its function is to provide a means for sports activities, recreation and the lungs of the city. There is a burial area located about 500 meters from the area of Perumnas Tanjung Karang Permai which is dedicated to residents Perumnas Tanjung Karang Permai Mataram. When referring to the Regional Regulation of Mataram City number 4 in 2016 Article 12, a housing should provide a burial area of $2 \%$ of the land area of residential. If it is viewed as the standard of SNI 03-1733-2004 with the population of 120,000 residents, it needs a burial area. While the number of residents Perumnas Tanjung Karang Permai which are 5506 inhabitants, there is a burial area for Perumnas Tanjung Karang Permai. It means that the standard is feasible because the burial area in Perumnas Tanjung Karang Permai is 2,600 m2.

\subsection{Recapitulation of Analysis of Social Facilities in Perumnas Tanjung Karang Permai Mataram}

This analysis is a recapitulation based on data obtained in which it was recorded that the population of Perumnas Tanjung Karang Permai has an area of $261.401 \mathrm{~m} 2$ with a population of 5506 residents.

Fibrianti, B., Sulistiyono, H., \& Hartana, -. (2018). A feasibility study for social and general facilities in Perumnas Tanjung Karang Permai Mataram. International Journal Of Physical Sciences And Engineering (IJPSE), 
Table 3

Recapitulation Table of the Analysis of Availability, Condition, and Management of Social Facilities based on SNI 03-1733-2004

\begin{tabular}{|c|c|c|c|c|c|c|c|}
\hline \multirow[t]{2}{*}{ NO } & \multirow{2}{*}{$\begin{array}{l}\text { Facilities } \\
\text { needed }\end{array}$} & \multicolumn{2}{|c|}{ SNI 03-1733-2004 } & \multirow[t]{2}{*}{ Availability } & \multirow[t]{2}{*}{ Condition } & \multirow[t]{2}{*}{ Management } & \multirow{2}{*}{$\begin{array}{l}\text { Additional } \\
\text { Information }\end{array}$} \\
\hline & & $\begin{array}{l}\text { Standar } \\
\operatorname{dm} 2 / \\
\text { resident }\end{array}$ & Land needed & & & & \\
\hline I & \multicolumn{7}{|c|}{ Governmental Facilities and Public Services } \\
\hline 1. & Meeting Hall & 0.12 & $\begin{array}{l}0.12 \times 5.506 \\
\text { resident } \\
=660 \mathrm{~m} 2\end{array}$ & $\begin{array}{l}\text { Area }= \\
2.000 \mathrm{~m} 2\end{array}$ & Good & $\begin{array}{c}\text { Good } \\
\text { By government }\end{array}$ & $\begin{array}{l}\text { Meet the } \\
\text { standard }\end{array}$ \\
\hline 2. & $\begin{array}{l}\text { Security } \\
\text { posture dan } \\
\text { electrical } \\
\text { relay station }\end{array}$ & 0.012 & $\begin{array}{l}0.012 \times 5.506 \\
\text { resident } \\
=64 \mathrm{~m} 2\end{array}$ & $\begin{array}{l}\text { Area }= \\
148 \mathrm{~m} 2\end{array}$ & Good & $\begin{array}{c}\text { Good } \\
\text { Security } \\
\text { posture by } \\
\text { community } \\
\text { electrical relay } \\
\text { station by } \\
\text { government }\end{array}$ & $\begin{array}{l}\text { Meet the } \\
\text { standard }\end{array}$ \\
\hline 3. & Park Area & 0.04 & $\begin{array}{l}0.04 \times 5.506 \\
\text { resident } \\
=220.24 \mathrm{~m} 2\end{array}$ & $\begin{array}{l}\text { Area }= \\
1.250 \mathrm{~m} 2\end{array}$ & Acceptable & $\begin{array}{c}\text { Acceptable } \\
\text { By } \\
\text { Tanjung } \\
\text { Karang village } \\
\end{array}$ & $\begin{array}{l}\text { Meet the } \\
\text { standard }\end{array}$ \\
\hline 4. & Head Office & 0.033 & $\begin{array}{l}0.033 \times 5.506 \\
\text { resident } \\
=181.6 \mathrm{~m} 2\end{array}$ & $\begin{array}{l}\text { Area }= \\
1.900 \mathrm{~m} 2\end{array}$ & Good & $\begin{array}{c}\text { Good } \\
\text { By Government }\end{array}$ & $\begin{array}{l}\text { Meet the } \\
\text { standard }\end{array}$ \\
\hline II & \multicolumn{7}{|c|}{ Education and Learning Facilities } \\
\hline 1. & $\begin{array}{l}\text { Kindergarten } \\
\text { and } \\
\text { Elementary } \\
\text { School }\end{array}$ & 1.25 & $\begin{array}{l}1.25 \times 5.506 \\
\text { resident } \\
=6.882 \mathrm{~m} 2\end{array}$ & $\begin{array}{l}\text { Area } \\
\text { Kindergarten } \\
=5472 \text {, } \\
\text { Area of SDN } \\
37 \mathrm{Amp} \\
3.265 \mathrm{~m} 2, \mathrm{SD} \\
38 \mathrm{Amp}= \\
2.336 \mathrm{~m} 2\end{array}$ & Good & $\begin{array}{c}\text { Good } \\
\text { By Government }\end{array}$ & $\begin{array}{l}\text { Meet the } \\
\text { standard }\end{array}$ \\
\hline 2. & $\begin{array}{l}\text { Junior High } \\
\text { School }\end{array}$ & 1.88 & $\begin{array}{l}1.88 \times 5.506 \\
\text { resident = } \\
10.351 \mathrm{~m} 2\end{array}$ & - & - & - & $\begin{array}{l}\text { unmeet the } \\
\text { standard }\end{array}$ \\
\hline 3. & $\begin{array}{l}\text { Senior High } \\
\text { School }\end{array}$ & 2.6 & $\begin{array}{l}2.6 \times 5.506 \\
\text { resident = } \\
14.315 \mathrm{~m} 2\end{array}$ & - & - & - & $\begin{array}{l}\text { Unmeet the } \\
\text { standard }\end{array}$ \\
\hline 4. & $\begin{array}{l}\text { Taman } \\
\text { Bacaan }\end{array}$ & 0.09 & $\begin{array}{l}0.09 \times 5.506 \\
\text { resident } \\
=495.5 \mathrm{~m} 2\end{array}$ & $\begin{array}{l}\text { Area }= \\
500 \mathrm{~m} 2\end{array}$ & Good & $\begin{array}{c}\text { Good } \\
\text { By Community }\end{array}$ & $\begin{array}{l}\text { Meet the } \\
\text { standard }\end{array}$ \\
\hline III & \multicolumn{7}{|c|}{ Health Facilities } \\
\hline 1. & $\begin{array}{l}\text { Maternal and } \\
\text { Child Health } \\
\text { Service }\end{array}$ & 0.048 & $\begin{array}{l}0.048 \times 5.506 \\
\text { resident } \\
=264.28 \mathrm{~m} 2\end{array}$ & $\begin{array}{l}\text { Area }= \\
300 \mathrm{~m} 2\end{array}$ & Good & $\begin{array}{c}\text { Good } \\
\text { By Community }\end{array}$ & $\begin{array}{l}\text { Meet the } \\
\text { standard }\end{array}$ \\
\hline 2. & Community & 0.006 & $0.006 \times 5.506$ & Area $=$ & Good & Good & Meet the \\
\hline
\end{tabular}




\begin{tabular}{|c|c|c|c|c|c|c|c|}
\hline & Health Clinic & & $\begin{array}{l}\text { resident } \\
=33 \mathrm{~m} 2\end{array}$ & $105 \mathrm{~m} 2$ & & By Government & standard \\
\hline 3. & $\begin{array}{l}\text { Private Clinic } \\
\text { of Doctor and } \\
\text { midwife and } \\
\text { drugstore }\end{array}$ & 0.026 & $\begin{array}{l}0.026 \times 5.506 \\
\text { resident } \\
=143 \mathrm{~m} 2\end{array}$ & $\begin{array}{c}\text { Area }= \\
1.200 \mathrm{~m} 2\end{array}$ & Good & $\begin{array}{l}\text { Good } \\
\text { By Community } \\
\text { (individually) }\end{array}$ & $\begin{array}{l}\text { Meet the } \\
\text { standard }\end{array}$ \\
\hline IV & \multicolumn{7}{|c|}{ Worship Facilities } \\
\hline 1. & $\begin{array}{l}\text { Mashallah } \\
\text { and mosque }\end{array}$ & 0.36 & $\begin{array}{l}0.36 \times 5.506 \\
\text { resident } \\
=1.982 \mathrm{~m} 2\end{array}$ & $\begin{array}{l}\text { Area }= \\
336 \mathrm{~m} 2 \\
\text { Luas lahan = } \\
2.258 \mathrm{~m} 2\end{array}$ & Good & $\begin{array}{l}\text { Mosque is Good } \\
\text { By Government }\end{array}$ & $\begin{array}{l}\text { Meet the } \\
\text { standard }\end{array}$ \\
\hline 2. & Shrine & $\begin{array}{c}- \\
\text { (no } \\
\text { standard } \\
\text { of SNI } \\
03- \\
1733- \\
2004 \text { ) }\end{array}$ & $\begin{array}{c}- \\
\text { (no standard } \\
\text { of SNI 03- } \\
\text { 1733-2004) }\end{array}$ & $\begin{array}{l}\text { Area }= \\
550 \mathrm{~m} 2\end{array}$ & Good & $\begin{array}{c}\text { Good } \\
\text { By Community }\end{array}$ & $\begin{array}{l}\text { Meet the } \\
\text { standard }\end{array}$ \\
\hline $\mathrm{V}$ & \multicolumn{7}{|c|}{ Trade and Commerce Facilities } \\
\hline 1. & $\begin{array}{l}\text { Shop/ } \\
\text { \& service }\end{array}$ & 0.4 & $\begin{array}{l}0.4 \times 5.506 \\
\text { resident } \\
=2.202 \mathrm{~m} 2\end{array}$ & $\begin{array}{l}\text { Area }= \\
8.921 \mathrm{~m} 2\end{array}$ & Good & $\begin{array}{c}\text { Good } \\
\text { By Community }\end{array}$ & $\begin{array}{l}\text { Meet the } \\
\text { standard }\end{array}$ \\
\hline 2. & Market & 0.33 & $\begin{array}{l}0.33 \times 5.506 \\
\text { resident } \\
=1.816 \mathrm{~m} 2\end{array}$ & $\begin{array}{l}\text { Area }=1.900 \\
\mathrm{~m} 2\end{array}$ & Good & $\begin{array}{c}\text { Good } \\
\text { By Government } \\
\text { and community }\end{array}$ & $\begin{array}{l}\text { Meet the } \\
\text { standard }\end{array}$ \\
\hline VI & \multicolumn{7}{|c|}{ Open Space Facilities, Parks and Sports Field } \\
\hline 1. & $\begin{array}{l}\text { Playground } \\
\text { and } \\
\text { Sport Area }\end{array}$ & 0.5 & $\begin{array}{l}0.5 \times 5.506 \\
\text { resident } \\
=2.753 \mathrm{~m} 2\end{array}$ & $\begin{array}{l}\text { Area }= \\
13.837 \mathrm{~m} 2\end{array}$ & $\begin{array}{l}\text { Playground } \\
\text { id Poor } \\
\text { While Sport } \\
\text { are is good }\end{array}$ & $\begin{array}{l}\text { The playground } \\
\text { is not well } \\
\text { organized by } \\
\text { community and } \\
\text { government } \\
\text { sports area is } \\
\text { well organized } \\
\text { by community } \\
\text { and government }\end{array}$ & $\begin{array}{l}\text { Meet the } \\
\text { standard }\end{array}$ \\
\hline 2. & Burial Area & - & - & $\begin{array}{c}\text { Area }= \\
2.600 \mathrm{~m} 2\end{array}$ & Good & $\begin{array}{c}\text { Good } \\
\text { By Community }\end{array}$ & $\begin{array}{l}\text { Meet the } \\
\text { standard }\end{array}$ \\
\hline
\end{tabular}

Referring to the recapitulation table of the analysis of availability, condition and management of social facilities based on SNI 03-1733-2004, it can be said that government and public service facilities, education and learning facilities, health facilities, worship facilities, trade and commerce facilities as well as open space, playground and sports field mostly meet the standards of SNI 03-1733-2004.

Fibrianti, B., Sulistiyono, H., \& Hartana, -. (2018). A feasibility study for social and general facilities in Perumnas Tanjung Karang Permai Mataram. International Journal Of Physical Sciences And Engineering (IJPSE), 2(1), 57-70. doi:10.29332/ijpse.v2n1.130 
Table 4

Table of Recapitulation of Availability, Condition, and Management of Public Facilities based on SNI 03-17332004

\begin{tabular}{|c|c|c|c|c|c|c|}
\hline No & $\begin{array}{c}\text { Facilities } \\
\text { Needed }\end{array}$ & SNI 03-1733-2004 & Availability & Condition & Management & $\begin{array}{l}\text { Additional } \\
\text { Information }\end{array}$ \\
\hline 1. & Drainage & - Complement building & - Culvert & Acceptable & $\begin{array}{c}\text { Goodby } \\
\text { Government } \\
\text { And community }\end{array}$ & $\begin{array}{l}\text { Met the } \\
\text { standard }\end{array}$ \\
\hline 2 & Sewerage & $\begin{array}{l}\text { - Ketersediaan jamban } \\
\text { keluarga dan jamban } \\
\text { jamak. (data primer } \\
\text { dan sekunder) } \\
\text { - Availability of family } \\
\text { latrines and public } \\
\text { latrines. (Primary } \\
\text { and Secondary Data) } \\
\text { - Availability of septic } \\
\text { tank (primary data) }\end{array}$ & $\begin{array}{l}\text { a) septic tank } \\
\text { b)absorber } \\
\text { field } \\
\text { c) } \\
\text { wastewater } \\
\text { network }\end{array}$ & Acceptable & $\begin{array}{c}\text { Goodby } \\
\text { Government } \\
\text { And community }\end{array}$ & $\begin{array}{l}\text { Met the } \\
\text { standard }\end{array}$ \\
\hline 3. & Garbage & $\begin{array}{l}\text { - Trash bin } \\
(\min .2 \mathrm{~m} 2) \\
\text { - Small Trash bin (min. } \\
6 \mathrm{~m} 2)\end{array}$ & $\begin{array}{l}\text { Container } \\
1 \text { unit }\end{array}$ & Good & $\begin{array}{c}\text { Goodby } \\
\text { Government } \\
\text { And community }\end{array}$ & $\begin{array}{l}\text { Met the } \\
\text { standard }\end{array}$ \\
\hline 4. & local roads & $\begin{array}{l}\text { Local Secondary I } \\
(3.0-7.0 \mathrm{~m}) \\
\text { - Local Secondary II } \\
(3.0-6.0 \mathrm{~m}) \\
\text { - Local Secondary III } \\
(3.0 \mathrm{~m}) \\
\text { - Environment I } \\
(1.5-2.0 \mathrm{~m}) \\
\text { Environment II } \\
(1.2 \mathrm{~m})\end{array}$ & $\begin{array}{l}\text { Local } \\
\text { Secondary }\end{array}$ & Good & $\begin{array}{c}\text { Goodby } \\
\text { Government }\end{array}$ & $\begin{array}{l}\text { Met the } \\
\text { standard }\end{array}$ \\
\hline
\end{tabular}

Referring to the recapitulation table of the analysis of availability, condition, and management of public facilities based on SNI 03-1733-2004, it can be said that drainage, wastewater, garbage and road network are met the standard. However, closer attention is needed from community and government for condition and management of drainage and wastewater network

\section{Conclusion}

Based on the discussion above, it can be concluded that (1) in general, Social Facility and Public Facilities of Perumnas Tanjung Karang Permai has reached 34\% of total Perumnas area, already fulfill SNI 03-17332004 standard and Mataram City Regulation No 4 year 2016 article 9 on the provision of social facilities and public facilities at least $30 \%$ of the total land area, (2) the availability of public facilities and social facilities, in general, meets the standards of SNI 03-1733-2004, only on the parking lot is still not meet the standard because there is no facility specifically for the management of parking for residents who own car but do not have a parking area in the yard of his or her house or for visitors. This causes the existing road areas to be disturbed by the use of parking on the road, (3) the condition of the Social Facilities and Public Facilities of 
Tanjung Karang Permai Perumnas is generally good and acceptable, the only playground is is in not good condition, and (4) the management of Social Facility in Perumnas Tanjung Karang Permai is managed by the government and the community, while the Public Facility of Perumnas Tanjung Karang Permai is managed by the government, the residents are limited to caring for and maintaining cleanliness.

Perumnas Tanjung Karang Permai as the oldest housing in Mataram City generally has social facilities and public facilities that meet the standards set by the government in a housing complex. Some notions that can be suggested for improvement or perfection of social facilities and public facilities in Perumnas Tanjung Karang Permai are:

1) The availability of parking which are for residents who own car but does not have a parking area in the yard of his house or for visitors needs to have the attention to avoid the use of secondary road and road environment.

2) Improvement of physical condition in playground area is needed to provide facilities for the growth of children in Perumnas Tanjung Karang Permai.

3) Good coordination and communication between the Perumnas Tanjung Karang Permai community and the government in the management of social facilities and public facilities are demanded so that the availability and physical condition can be maintained.

4) For new housing developers, it is necessary to refer to Perumnas Tanjung Karang Permai in order to be able to meet the availability of social facilities and public facilities in line with the standards set by the government.

Conflict of interest statement and funding sources

The authors declared that they have no competing interest. The study was financed by personal funding.

Statement of authorship

The authors have a responsibility for the conception and design of the study. The authors have approved the final article.

\section{Acknowledgments}

The researcher s to express his great gratitude to all people who have helped a lot during this study. To the author's parent and a husband who give high motivation, prayer, and other non-material support. To all the lecturers in the master program of civil engineering who have been patiently sharing knowledge as long as the writers study in this program

Fibrianti, B., Sulistiyono, H., \& Hartana, -. (2018). A feasibility study for social and general facilities in Perumnas Tanjung Karang Permai Mataram. International Journal Of Physical Sciences And Engineering (IJPSE), 


\section{References}

1. Adimagistra, T., \& Pigawati, B. (2016). Evaluasi Penyediaan Sarana Dan Prasarana Di Perumahan Puri Dinar Mas Semarang. Jurnal Pengembangan Kota, 4(1), 58-66.

View in (Google Scholar)

2. Budi, D. S. (2005). Pembangunan Kota, Tinjauan Regional dan Lokal.

View in (Google Scholar)

3. Budihardjo, E. (2009). Perumahan dan Permukiman di Indonesia. Bandung: Alumni.

View in (Google Scholar)

4. Castillo, G. A. L., Álava, L. A. C., Fernández, M. C., \& Llanes, M. V. (2017). Roadmap for the Introduction of Smart Grids in Ecuador. International Journal of Physical Sciences and Engineering (IJPSE), 1(2), 1-10.

View in (Google Scholar)

5. Cedeño, M. L. D., Arteaga, M. G. D., Pérez, A. V., \& Arteaga, M. L. D. (2017). Regulatory Framework for Renewable Energy Sources in Ecuador Case Study Province of Manabí. International Journal of Social Sciences and Humanities (IJSSH), 1(2), 29-42.

View in (Google Scholar)

6. Chilán, J. C. H., Torres, S. G. P., Machuca, B. I. F., Cordova, A. J. T., Pérez, C. A. M., \& Gámez, M. R. (2018). Social Impact of Renewable Energy Sources in the Province of Loja. International Journal of Physical Sciences and Engineering (IJPSE), 2(1), 13-25.

View in (Google Scholar)

7. Indonesia, P. R. (2006). Peraturan pemerintah republik indonesia nomor 69 tahun 2001 tentang kepelabuhanan.

View in (Google Scholar)

8. Indonesia, P. R., \& Indonesia, P. R. (1992). Undang Undang No. 23 Tahun 1992 Tentang: Kesehatan. Undang Undang, (23), 1-31.

View in (Google Scholar)

9. Indonesia, P. R., \& Indonesia, P. R. (1992). Undang Undang No. 23 Tahun 1992 Tentang: Kesehatan. Undang Undang, (23), 1-31.

View in (Google Scholar)

10. Indonesia, R., \& ESA, D. R. T. Y. M. (1992). Undang-undang Republik Indonesia Nomor 4 Tahun 1992 Tentang. Perumahan dan Permukiman.

View in (Google Scholar)

11. Indonesia, R., Peraturan, B. P. K., \& No, R. I. (2004). Undang-undang Republik Indonesia Nomor 15 Tahun 2004 tentang Pemeriksaan Pengelolaan dan Tanggung Jawab Keuangan Negara. bpk. go. id [5 Maret 2016]. View in (Google Scholar)

12. Keman, S. (2005). Kesehatan perumahan dan lingkungan pemukiman. Jurnal Kesehatan Lingkungan, 2(1). View in (Google Scholar)

13. Kristiansen, S., \& Trijono, L. (2005). Authority and law enforcement: local government reforms and security systems in Indonesia. Contemporary Southeast Asia, 236-254.

View in (Google Scholar) 
14. KUSUMO, B. L. S. B. A. (2012). Implementasi Peraturan Pemerintah Republik Indonesia Nomor 2 Tahun 2003 Tentang Peraturan Disiplin Angggota Polisi Republik Indonesia Di Poltabes Surakarta. Dinamika Hukum, 1(2).

View in (Google Scholar)

15. Kuswartojo, T. (2005). Perumahan dan permukiman di Indonesia. Upaya membuat perkembangan kehidupan yang berkelanjutan, Penerbit ITB.

View in (Google Scholar)

16. Moleong, L. J. (1999). Metodologi penelitian. Bandung: PT. Remaja Rosda Karya. View in (Google Scholar)

17. Nasional, B. S. (2004). Tata cara perencanaan lingkungan perumahan di perkotaan. Badan Standar Nasional Indonesia. Jakarta. View in (Google Scholar)

18. Nomor, P. M. D. N. (9). Tahun 2009 tentang Pedoman Penyerahan Prasarana. Sarana dan Utilitas Perumahan dan Permukiman di Daerah.

View in (Google Scholar)

19. Pranoto, A. B. (2007). Hubungan Kepadatan Pemukiman Dengan Ketersediaan Infrasruktur(Doctoral dissertation, Program Pascasarjana Universitas Diponegoro).

View in (Google Scholar)

20. Raharjo, N. P. (2010). Dinamika Pemenuhan Kebutuhan Perumahan Masyarakat Berpenghasilan Rendah (Studi kasus: Penghuni Rumah Tipe Kecil Griya Pagutan Indah, Mataram) (Doctoral dissertation, Universitas Diponegoro).

View in (Google Scholar)

21. Rakyat, M. N. P. (2007). Peraturan Menteri Negara Perumahan Rakyat No. 18/PERMEN/M/2007 tentang Petunjuk Pelaksanaan Perhitungan Tarif Sewa Rumah Susun Sederhana yang Dibiayai APBN dan APBD. View in (Google Scholar)

22. Sanropie, D. (1992). Pedoman Bidang Studi Perencanaan Penyehatan Lingkungan Pemukiman. Jakarta: Departemen Kesehatan RI.

View in (Google Scholar)

23. Subagyo, A. (2007). Studi Kelayakan. Elex Media Komputindo. View in (Google Scholar)

24. Tufail, Muhammad, Koko Dwi Sutanto, Said El Salamouny, Muhammad Tufail, Khawaja Ghulam Rasool, Sukirno Sukirno, Merle Shepard, Martin Shapiro, and Abdulrahman Saad Aldawood. "AiMOS 2.0." View in (Google Scholar)

25. Umum, D. P. (1987). Petunjuk perencanaan kawasan perumahan kota. Yayasan Badan Penerbit PU, Jakarta. View in (Google Scholar)

26. Umum, K. P., \& Indonesia, R. (1998). Persyaratan Teknis Aksesibilitas Pada Bangunan Umum dan Lingkungan. Direktorat Bina Teknik. Jakarta.

View in (Google Scholar)

Fibrianti, B., Sulistiyono, H., \& Hartana, -. (2018). A feasibility study for social and general facilities in Perumnas Tanjung Karang Permai Mataram. International Journal Of Physical Sciences And Engineering (IJPSE), 2(1), 57-70. doi:10.29332/ijpse.v2n1.130 


\section{Biography of Authors}

\begin{tabular}{|l|l|}
\hline Bq. Susdiana Fibrianti was born in Mataram, February 5, 1977. She completed her \\
education from primary study to high school in her hometown. She earned her \\
Bachelor degree of Architecture in Faculty of Engineering, Islamic University of \\
Indonesia. Now she is a graduate student of Civil Engineering program at Mataram \\
University. \\
Email: susdiana_fibriantivivin@yahoo.com
\end{tabular}

